\title{
Physicochemical characterisation of the postharvest senescence of the winter melon 'Tendral'
}

Maria da Graça Barreiro ${ }^{a \star}$, Fernando Cebola Lidon ${ }^{b}$, Manuela Pinto ${ }^{a}$

a Plant Physiology Department, Estação Agronómica Nacional, Avenida Republica,

Nova Oeiras,

2784-505 Oeiras,

Portugal

(mgbarreiro@mail.pt)

b Grupo de Disciplinas de Biologia Vegetal,

Faculdade de Ciências

e Tecnologia,

Universidade Nova de Lisboa,

Quinta da Torre,

2825 Monte da Caparica,

Portugal

(fjl@mail.fct.unl.pt)
${ }^{*}$ Correspondence and reprints

Received 9 June 2000 Accepted 16 October 2000

Fruits, 2001, vol. 56, p. 51-58 (c) $2001 \mathrm{Cirad} /$ EDP Sciences All rights reserved

Resumen Español, p. 58

\section{Physicochemical characterisation of the postharvest senescence of the winter melon 'Tendral'.}

Abstract - Introduction. Tendral type muskmelon is a winter melon fruit having a dark green skin slightly netted and crisp and a white sweet flesh with a long storage life. Materials and methods. The senescence of the mesocarp of the winter melon Cucumis melo L. (Inodorus Group) Tendral, stored at $12^{\circ} \mathrm{C}$ and ca. $75 \%$ relative humidity, was investigated during $100 \mathrm{~d}$ after harvest. Results. During storage, starch and sucrose become increasingly hydrolysed while the levels of reducing sugars increased. In this period the firmness and titratable acidity decreased, but an increase was found for protein and lipoperoxide concentrations. The colour parameters $\mathrm{L}$, a and $\mathrm{b}$ were also affected, $\mathrm{b}$ showing the langest increase after harvest. Ethylene concentration remained minimal but the production of carbon dioxide varied significantly. The activities of catalase and glutathione reductase increased whereas ascorbate peroxidase and superoxide dismutase were inhibited. Discussion. The senescence of winter melon Tendral is coupled to starch and sucrose consumption and to the synthesis of organic acids required for the respiratory metabolism. Hydrogen peroxide and superoxide also seem to accumulate, triggering the lipoperoxidation of cellular membranes at a low rate.

Portugal / Cucumis melo / postharvest physiology / chemicophysical properties / storage / quality

\section{Caractérisation physicochimique de la sénescence après récolte du melon d'hiver «Tendral ».}

Résumé - Introduction. Le melon «Tendral »de type cantaloup est un fruit d'hiver à peau vert-foncé avec un léger filet ; il a une chair douce et blanche et présente une longue durée de vie en stockage. Matériel et méthodes. La sénescence du mésocarpe du melon d'hiver Cucumis melo L (du groupe Inodorus) Tendral, stocké à $12{ }^{\circ} \mathrm{C}$ et à peu près $75 \% \mathrm{~d}$ 'humidité relative, a été examinée pendant 100 jours après la récolte. Résultats. Pendant le stockage, l'amidon et le saccharose ont été de plus en plus hydrolysés, alors que les taux de sucres réducteurs augmentaient. Pendant cette période, la fermeté et l'acidité titrable ont diminué, mais les concentrations en protéines et lipoperoxydes ont augmenté. Les paramètres de couleur $\mathrm{L}$, a et $\mathrm{b}$ ont été aussi affectés, le paramètre $\mathrm{b}$ ayant le plus augmenté après la récolte. La concentration d'éthylène est restée minimale, mais la production d'anhydride carbonique a changé de manière significative. Les activités de la catalase et de la glutathione reductase ont augmenté, tandis que celles de l'ascorbate peroxydase et de la superoxyde dismutase ont été inhibées. Discussion. La sénescence du melon d'hiver Tendral est couplée à la consommation d'amidon et de saccharose et à la synthèse des acides organiques nécessaires au métabolisme respiratoire. Le peroxyde d'hydrogène et le superoxyde semblent également s'accumuler, déclenchant une lente lipoperoxydation des membranes cellulaires.

Portugal / Cucumis melo / physiologie après récolte / propriété physicochimique / stockage / qualité 


\section{Introduction}

Tendral type muskmelon is a winter melon fruit having a dark green skin slightly netted and crisp, and a white sweet flesh with a long storage life. After harvesting, the firmness of the flesh and the concentration of soluble solids, sugars and protein becomes increasingly affected [1]. The alteration of the ethylene and respiration rates also indicate significant metabolic changes $[2,3]$. The involvement of ethylene in the processes of senescence is well known [4] and, furthermore, respiration is an important factor in post-harvest shelf life or senescence. In this context, the production and control of oxy radicals play a fundamental role. To living cells, dioxygen is at the same time both useful and toxic. Throughout univalent reductions, dioxygen produces strongly reactive chemical entities such as superoxide and hydroxyl radicals, as well as hydrogen peroxide. These chemical species can oxidise acyl lipids, namely in cellular membranes, increasing the rate of senescence. Even though such chain reactions can seriously amplify the damage caused by the initiating radical, the cells contain antioxidant systems (e.g., tocopherols and ascorbic acid) which interrupt free radical chain reactions, decreasing the damage done per radical initiator $[5,6]$. Nevertheless, during senescence, these chemical entities increase through inactivation of the antioxidant systems. Thus, depending on rates of production and control of oxy radicals, cellular degradation after harvest might be accelerated or retarded.

In this work, we investigated the alterations of fruit quality during $100 \mathrm{~d}$ following harvest and the cellular damage associated with the production and control of oxy radicals and hydrogen peroxide.

\section{Materials and methods}

In 1998, fruits belonging to the portuguese winter melon (Cucumis melo L inodorus group Tendral) were produced in the region of Évora (Portugal), from seeds stored in the germplasm bank of the Estação Agronómica Nacional, Instituto Nacional de Investigaçáo Agrária, Oeiras, Portugal. In early September, these fruits were collected, dipped in a 5\% sodium hypochloride during 5 min, dried overnight at room temperature and, thereafter, stored at $12{ }^{\circ} \mathrm{C}$ and $75 \%$ relative humidity during all the experimental period.

\subsection{Carbohydrates, protein and acyl lipoperoxides}

Reducing sugars and sucrose were measured using $25 \mathrm{~g}$ of the equatorial middle flesh. Samples were boiled in $250 \mathrm{~mL}$ of deionised water for $5 \mathrm{~min}$ to inactivate soluble acid invertase activity $[7,8]$. The solution was filtered using filter paper (Whatman $n^{\circ} 4$ ). For quantification of reducing sugars, the Sumner reagent was applied and the absorbance determined at $540 \mathrm{~nm}$. A glucose standard curve was used. Total carbohydrates were determined after hydrolysis with acid invertase. Sucrose concentration was obtained by subtracting reducing sugars from total sugars. Starch concentration was determined using the reaction iode / potassium iodine [9]. The absorbance was recorded at $620 \mathrm{~nm}$. All the carbohydrate measurements were carried out at harvest and 39, 70 and $98 \mathrm{~d}$ after harvesting using five replicates. Protein content was determined following Lowry et al. [10] with minor modifications to minimise the absorbance of interfering substances [11]. Five replicates belonging to five fruits were used 16, 41, 72 and $100 \mathrm{~d}$ after harvest. Acyl lipid peroxidation followed the thiobarbituric acid (TBA) [12], using three replicates from five fruits and was measured 15, 42, 71 and $99 \mathrm{~d}$ after harvest. This test, which determines malonaldehyde as an end product of lipid peroxidation was determined using $0.1 \%$ of trichloracetic acid (TCA) solution. Homogenates were centrifuged at $15000 \times \mathrm{g}$ for $10 \mathrm{~min}$ and $0.5 \mathrm{~mL}$ of the supernatant obtained was added to $1.5 \mathrm{~mL} \mathrm{0.5 \%} \mathrm{TBA} \mathrm{in} \mathrm{20 \%} \mathrm{TCA.} \mathrm{The} \mathrm{mixture}$ was incubated at $90{ }^{\circ} \mathrm{C}$ in a shaking water bath, and the reaction stopped by placing the reaction tubes in an ice-water bath. The samples were then centrifuged at $10000 \times \mathrm{g}$ for $5 \mathrm{~min}$ and the absorbance of the 
supernatant was read at $532 \mathrm{~nm}$. The absorbance at 440 and $600 \mathrm{~nm}$ was also determined to minimise the interference of carbon skeletons. A coefficient of $155 \mathrm{mM} \cdot \mathrm{cm}^{-1}$ was used.

\subsection{Flesh firmness and colour, total soluble solids and titratable acidity}

Colour, total soluble solids and titratable acidity followed Alavoine et al. [13], using five replicates of five fruits. Flesh firmness was estimated in the equatorial hypodermal mesocarp tissue, using a Magness-Taylor penetrometer by the resistance of the flesh to the penetration of a standard plunger with a diameter of $8 \mathrm{~mm}$ and a convex tip and expressed in Newtons. The firmness was measured on three opposite sides in the centre of the equatorial mesocarp region. The pulp colour was measured using a Minolta Chromameter CR-300 (Japan), based on the light transmittance. The colour values are expressed on the CIE (Commission Internationale de l'Éclairage) 1976 colour system with the L*a*b* axis representing lightness, green-red and blue-yellow, respectively. A hand refractometer Atago ATC-1 was used for measuring total soluble solids in extracted juice at a temperature of $20^{\circ} \mathrm{C}$, being the values expressed in ${ }^{\circ}$ Brix. All these parameters were determined 2, 40, 71 and $99 \mathrm{~d}$ after harvest.

\subsection{Ethylene and carbon dioxide}

Evolved ethylene and carbon dioxide were measured according to Meigh [14] and Dilley et al. [15], respectively. The winter melons were put in containers with a volume of ca. $6 \mathrm{~L}$ and at room temperature. Samples of $1 \mathrm{~mL}$ were therefore removed from the headspace 52, 72, $90 \mathrm{~d}$ after harvest and introduced in Gas Chromatographs Pye Unican Series 204 and 104 for measuring ethylene and carbon dioxide, respectively.

For ethylene determination, a $6 \mathrm{ft} \times 1 / 4^{\prime \prime}$ Porapak Q column and a flame ionization detector (FID) was used, being applied a nitrogen flow rate of $30 \mathrm{~mL} \mathrm{~min}^{-1}$ as a carrier gas. The temperatures were set to $90{ }^{\circ} \mathrm{C}$ for the oven, room temperature for the injection port, and $150{ }^{\circ} \mathrm{C}$ for the detector. Ethylene was identified and quantified by comparison with the peak area from the gas samples containing a known concentration (29 $\left.\mu \mathrm{L} \cdot \mathrm{L}^{-1}\right)$ of ethylene standard, being expressed as $\mu \mathrm{Lg}^{-1} \cdot \mathrm{h}^{-1}$.

Carbon dioxide was quantified using a CTR column (Altech catalogue number 8700 ) with a $6 \mathrm{ft} \times 1 / 4$ " inner column of a mixture of porous polymers (alumina) and a $6 \mathrm{ft} 1 / 8$ " outer column with molecular sieve and a thermal conductivity detector (TCD). The carrier gas was hydrogen at a flow rate of $50 \mathrm{~mL} \cdot \mathrm{min}^{-1}$. The oven and the injection port were maintained at room temperature, being the detector kept at $50{ }^{\circ} \mathrm{C}$. A $250 \mathrm{~mA}$ current was applied to the wheatstone bridge of the detector. Carbon dioxide was identified and quantified by comparison with the peak area from the gas samples containing a known concentration (5\%) of a carbon dioxide standard, being expressed as $\mathrm{mL} \cdot \mathrm{kg}^{-1} \cdot \mathrm{h}^{-1}$.

\subsection{Enzyme assays}

Ascorbate peroxidase (EC 1.11.1.7) activity was assayed 35, 70 and $98 \mathrm{~d}$ after harvest, using the method of Nakano and Asada [16]. The activity of glutathione reductase (EC 1.6.4.2) was measured 42, 70 and $98 \mathrm{~d}$ after harvest, according to the method of Dalton et al. [17]. Superoxide dismutase (EC 1.15.1.1) was determined 48 and $75 \mathrm{~d}$ after harvest, following the method of McCord and Fridovich [18]. The activity of catalase (EC 1.11.1.6) was measured 45, 70 and $98 \mathrm{~d}$ after harvest, according to the Patra et al. method [19]. The enzyme activities were expressed as follow: ascorbate peroxidase, $\mu \mathrm{mol}$ ascorbate consumed per mg protein per min; glutathione reductase, $\mu \mathrm{mol}$ of NADPH oxidised per mg protein per min; catalase, $\mu$ mol of $\mathrm{O}_{2}$ produced per mg protein per min; superoxide dismutase, units per mg protein (one unit being defined as the amount of enzyme required to inhibit the reduction rate of cyt c by $50 \%$ under the assay conditions). All these activities were carried out using discs from the centre of the mesocarp and considering triplicates from three fruits. 
Figure 1.

Concentrations

of carbohydrates in the flesh of winter melon Tendral until $99 \mathrm{~d}$ following harvest.

Each value is the mean of five replicates \pm standard error.

Different letters indicate significant differences in a multiple range analysis for $95 \%$ confidence level.

\section{Figure 2.}

Concentration of protein and lipoperoxides in the flesh of winter melon Tendral until $100 \mathrm{~d}$ following harvest.

Each value is the mean of five and three replicates \pm standard error. Different letters indicate significant differences in a multiple range analysis for $95 \%$ confidence level.

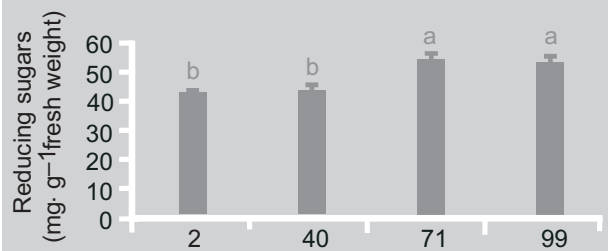

various studied parameters. Based on the ANOVA results, a Tukey's test was performed for mean comparison (for a 95\% confidence level).

\section{Results}
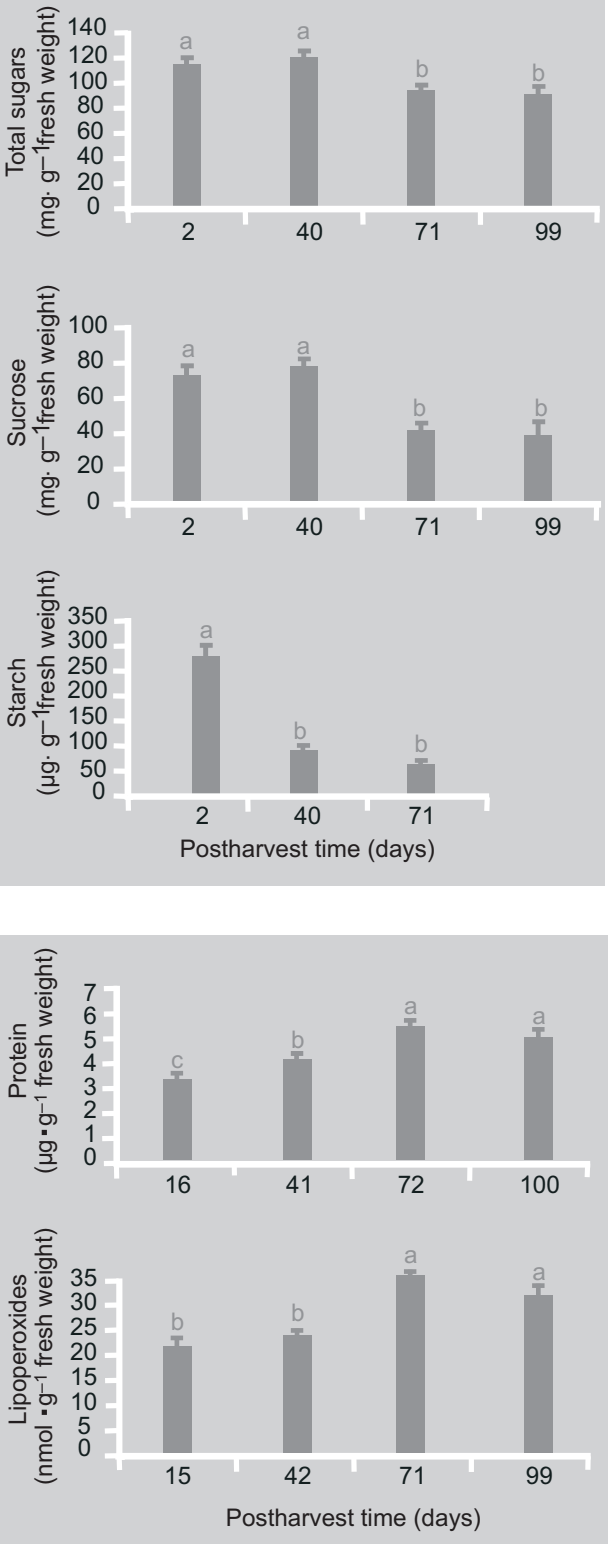

\subsection{Statistics}

The data were analysed statistically using one-way ANOVA $(p \leq 0.05)$ applied to the
In the flesh of winter melons, the concentration of starch decreased significantly (ca. 65\%) between harvest and $39 \mathrm{~d}$, but sucrose content only decreased to $50 \%$ after that period (figure 1). During the entire postharvest period, the concentration of total sugars only decreased slightly (19\%), whilst the reducing sugars increased $23 \%$ (figure 1). Between 16 and $72 \mathrm{~d}$ following harvest, the concentration of total protein increased significantly (30\%), but, thereafter, increased by $50 \%$ up to $71 \mathrm{~d}$ (figure 2). Acyl lipids peroxidation in these tissues did not vary significantly until the $42 \mathrm{~d}$ following harvest, but increased thereafter (50\%) until the $71 \mathrm{~d}$ (figure 2).

The firmness of the flesh decreased significantly by $70 \%$ after harvest within the first $40 \mathrm{~d}$, but remained constant thereafter (figure 3). Moreover, the titratable acidity steadily decreased to $30 \%$ of the initial value from harvest onwards (figure 3 ). The total soluble solids increased significantly (18\%) until the $40 \mathrm{~d}$ after harvest, but, thereafter, decreased continuously (figure 3 ). The colour expressed through parameter L decreased slightly, but significantly from the $40 \mathrm{~d}$ after harvest onwards, whereas the of storage. The parameter $\mathrm{b}$ showed the largest increase after harvest (figure 4) indicating an increase in the yellow colour. The concentration of evolved ethylene was low and did not vary significantly during storage (figure 5). The production of carbon dioxide sharply increased between 52 and $72 \mathrm{~d}$ after harvest but thereafter did not change significantly (figure 5). In the flesh, the enzymes maximum activities implicated in the control of the oxidative stress showed significant variations during the post harvest period (table I). The activity of ascorbate peroxidase decreased significantly (to 48\%) between 35 and $98 \mathrm{~d}$, yet, during this parameter a increased slightly until the end 
period, an opposite trend was found for glutathione reductase activity, which showed a 2.3 fold increase. Catalase activity revealed a 2.1 fold increase only between 70 and $98 d$, while superoxide dismutase decreased sharply between 48 and $75 \mathrm{~d}$.

\section{Discussion}

The winter melon Tendral does not accumulate significant reserves of carbohydrates, or high levels of total soluble solids. Until $98 \mathrm{~d}$ after harvest, the increasing contents of reducing sugars are closely associated to starch and sucrose hydrolysis [20-23]. These interacting effects clearly imply the occurrence of a high activity of acid invertase conducting to considerable increases of glucose, but the pattern of this enzyme activity is completely different from that expressed in hydric honey dew muskmelon, which becomes totally inhibited $50 \mathrm{~d}$ after anthesis [1]. Moreover, in spite of these effects in the metabolism of winter melon Tendral, the slight decrease of the content of total fruit sugars remained quite similar to that reported by Pratt et al. [2] in muskmelon, which is probably due to sucrose degradation. Eventually, these metabolisms are regulated by several well known factors, although also implicating a limited loss of the fruit moisture content [24]. Coupled to the alterations in carbohydrates, the sharp decrease of the flesh titratable acidity from harvest onwards is a definite indication that the catabolism of carbohydrates moving toward the synthesis of organic acids is imbalanced. Indeed, sugars might act as immediate precursors of organic acids, and the changes in acidity of the flesh is closely associated with these organic acids [3]. Thus, as found for many fruits [3], a consumption of organic acids also occurs during storage of winter melon Tendral. The higher respiration rates found during the storage period may indicate the increasing need of the carbon skeletons furnished by organic acids. The proteolysis and the subsequent catabolism of aminoacids eventually could provide some of the high levels of carbon required for the

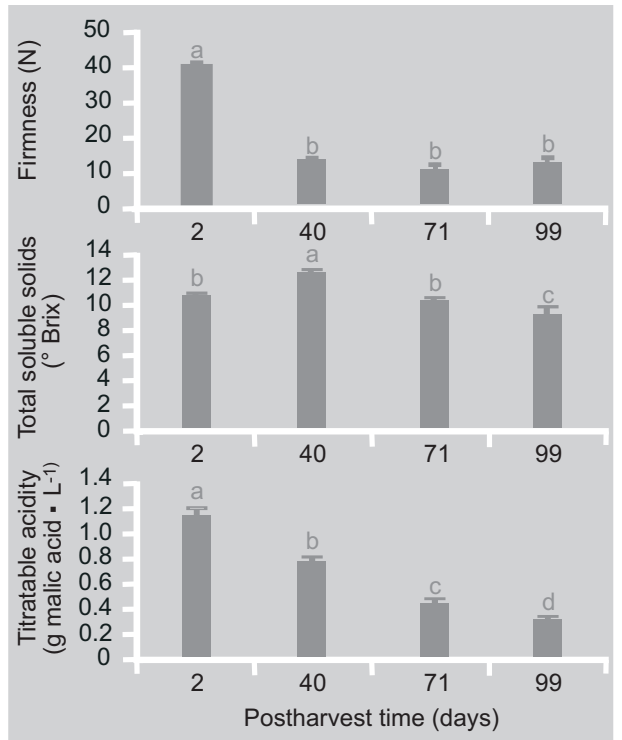

\section{Figure 3.}

Firmness, total soluble solids and acidity in the flesh of winter melon Tendral until $99 \mathrm{~d}$ following harvest. Each value is the mean of five replicates \pm standard error. Different letters indicate significant differences in a multiple range analysis for $95 \%$ confidence level.

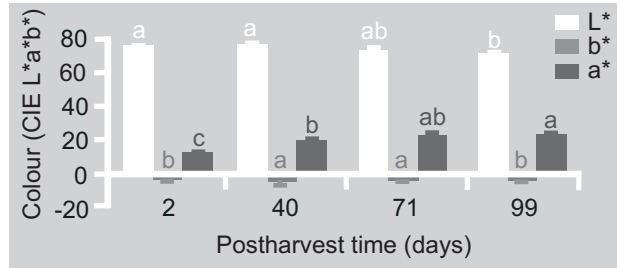

\section{Figure 4.}

Colour in the flesh of winter melon Tendral until $99 \mathrm{~d}$ following harvest. Each value is the mean of five replicates \pm standard error. Different letters indicate significant differences in a multiple range analysis for $95 \%$ confidence

functioning of the citric acid cycle, during the postharvest period. As protein concentration in the flesh of winter melon Tendral is ca. 5-fold higher than that usually found in other varieties of melon, namely honew dew [3], such metabolic function / action would be expected. However, the increasing levels of protein found until the end of the storage period definitively requires increasing synthesis. Indeed, during post harvest senescence, increasing accumulation of acyl lipids hydroperoxides strongly indicates the occurrence of structural

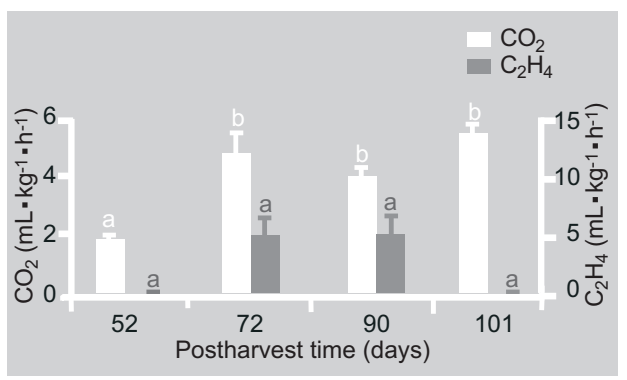

\section{Figure 5.}

Carbon dioxide and ethylene content of winter melon Tendral until $101 \mathrm{~d}$ following harvest. Each value is the mean of three replicates \pm standard error. Different letters indicate significant differences in a multiple range analysis for $95 \%$ confidence level. 


\section{Table I.}

Maximum activities of enzymes implicated in the control of the oxidative stress in the flesh of winter melon Tendral during $98 \mathrm{~d}$ following harvest. Each value is the mean of three replicates \pm standard error $(s)$.

\begin{tabular}{|c|c|c|c|c|}
\hline \multirow{2}{*}{$\begin{array}{l}\text { Days after } \\
\text { harvest }\end{array}$} & \multicolumn{4}{|c|}{ Enzymes maximum activities } \\
\hline & $\begin{array}{c}\text { Ascorbate peroxidase } \\
\left(\mu \mathrm{mol} \cdot \mathrm{mg}^{-1} \text { prot } \cdot \mathrm{min}^{-1} \pm s\right)\end{array}$ & 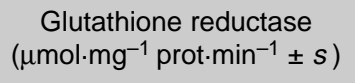 & $\begin{array}{c}\text { Catalase } \\
\left(\mu \mathrm{mol} \cdot \mathrm{mg}^{-1} \text { prot } \cdot \mathrm{min}^{-1} \pm s\right)\end{array}$ & $\begin{array}{l}\text { Superoxide dismutase } \\
\left(\text { Units } \cdot \mathrm{mg}^{-1} \text { prot } \pm s\right)\end{array}$ \\
\hline$[35-48]$ & $0.624 \pm 0.0292 a$ & $2.822 \pm 0.083 c$ & $11.675 \pm 0.632 b$ & $82.869 \pm 1.718 a$ \\
\hline 70 & $0.488 \pm 0.0138 b$ & $4.273 \pm 0.399 b$ & $9.769 \pm 0.360 b$ & $2.140 \pm 0.335 b$ \\
\hline 98 & $0.297 \pm 0.0084 c$ & $6.213 \pm 0.115 a$ & $20.428 \pm 0.722 a$ & n.d. \\
\hline
\end{tabular}

changes of the cellular membranes, which may imply an alteration of the protein patterns. Additionally, the sharp decrease of the firmness of the flesh in the first $40 \mathrm{~d}$ also indicates a significant textural alteration of the cell walls, which might be closely associated with increasing cellulase activity [25] or to other pectic enzymatic changes [20]. Accordingly, this further becomes a modelling peroxidative factor of the cellular membranes. Membrane degradation implied by the accumulation of hydroperoxides are modulated not only by oxygenation reactions attacking polyunsaturated fatty acids, but also by a general and progressive failure of the antioxidant enzymatic systems $[5,6]$. The enzyme kinetics in these peroxidative chain reactions suggests (as expressed by the increasing activity of catalase) a decreasing accumulation of hydrogen peroxide until the end of storage. The pattern developed by catalase activity eventually counterbalances the increasing inhibition of ascorbate peroxidase but does not avoid the blockage of the maximum activities attained for glutathione reductase due to substrate limitations. Additionally, the inhibition of superoxide dismutase might be associated to a decreased production of superoxide since an additional consumption of triplet oxygen follows the increasing rate of the cellular respiration. Thus, the senescence of winter melon Tendral does not seem to be linked to the synthesis of hydrogen peroxide and does not implicate a ping-pong mechanism coupled to the protonation of superoxide [5, 26]. Indeed, as it is long recognised, these chemical entities are produced in the hydrophobic regions of the biological membranes, inducing the peroxidation of acyl lipids [5, 27], and, possibly, mediating senescence [28]. Nevertheless, as shown by the low values of ethylene, senescence in winter melon Tendral was trigger, at least by oxy radicals, at a slow rate $[5,6]$. This definitively points a low production of alkoxy radicals (implicating Fenton-type reactions) or consumption of ethyl radicals [29, 30]. In the meanwhile, the increased synthesis of carotenoids (as evidenced by the changing colour of parameter b) might be an additional parameter limiting senescence. Indeed, carotenoids act as protective pigments through a direct deactivation of reactive forms of oxygen [31].

\section{Conclusion}

During storage of winter melon Tendral, starch and sucrose are increasingly hydrolysed allowing the rise of reducing sugars. The catabolism of these carbohydrates might be the source of the continuous synthesis of organic acids required for respiratory metabolism. Increasing protein concentration indicates that this chemical entity is not the source of carbon skeletons to the citric acid cycle. The flesh softening further indicates an increasing degradation of cellular walls and might facilitate acyl lipid 
peroxidation of membranes. This process seems to occur in the hydrophobic regions of the membranes, although implicating a slow production rate of hydrogen peroxide or protonation of superoxide. Indeed, the slow development of senescence seems coupled to the occurrence of limiting steps in the synthesis of ethylene through the linolenate pathway and, furthermore, might implicate an increased synthesis of isoprenoids.

\section{Acknowledgements}

This work was supported by the project PAMAF/IED no 3055 from the Ministry of Agriculture of Portugal.

The authors thank to Pr. Daryl G. Richardson (Oregon State University, USA) for the careful reading of the manuscript and his very useful suggestions and to Carlos Santiago de Carvalho as well as to Ana Paula Ramos (Plant Physiology Department of the Estação Agronómica Nacional, Instituto Nacional de Investigaçáo Agrária, Oeiras, Portugal) for technical assistance.

\section{References}

[1] Lester G., Physicochemical characterization of hybrid Honey Dew muskmelon fruits (Cucumis melo L. var. inodorus Naud.) following maturation, abscission and postharvest storage, J. Amer. Soc. Hort. Sci. 123 (1998) 126-129.

[2] Pratt H.K., Goeschl J.D., Martin F.W., Fruit growth and development, ripening and the role of ethylene in the "Honey Dew" muskmelon, J. Amer. Soc. Hort. Sci. 102 (1977) 203-210.

[3] Kays S.J., Postharvest physiology of perishable plant products, in: Development of Plants and Plant Parts, Van Nostrand Reinhold Publ., New York, 1991, pp. 257-335.

[4] Lesham Y., Halevy A., Frenkel C., Processes and control of plant senescence, Elsevier New York, 1986.

[5] Lidon F.C., Henriques F.S., Oxygen metabolism in higher plant chloroplasts, Photosynth. 29 (1993) 249-279.
[6] Pole A., Defense against photooxidative damage in plants, in: Oxidative stress and the molecular biology of antioxidant defenses, Cold Spring Harbor Laboratory Press, 1997, pp. 625-665.

[7] Sumner J.B., A more specific reagent for the determination of sugar in urine, J. Biol. Chem. 65 (1925) 393-396.

[8] Barreiro M.G., O Bitter pit da maçã [Bitter pit in apple], Faculdade de Ciências da Universidade de Lisboa, Portugal,1989.

[9] Nielson J.P., Rapid determination of starch An index to maturity in starchy vegetables, Ind. Eng. Chem. 15 (1943) 176-179.

[10] Lowry O.H., Rosebrough N.J., Farr A.L., Randall R.J., Protein measurement with the Folin phenol reagent, J. Biol. Chem. 193 (1951) 265-275.

[11] Lidon F.C., Effects of excess copper in rice: biochemical, physiological and ultrastrutural aspects, FCT/UNL Eds, $\mathrm{M}^{\text {te }}$ Caparica, Portugal, 1994.

[12] Lidon F.C., Teixeira M.G., Rice tolerance to excess $\mathrm{Mn}$ : implications in the chloroplast lamellae and synthesis of a novel Mn-protein, Plant Physiol. Biochem. (in press).

[13] Alavoine F., Crochon M., Fady C., Fallot J., Moras P., Pech J.C., La qualité des fruits, bases physiologiques et méthodes pratiques d'analyse, Cemagref-Dicova, Antony, 1988.

[14] Meigh D.E., Norris K.H., Craft C.C., Lieberman M. Ethylene production by tomato and apple fruits, Nature 186 (1960) 902-903.

[15] Dilley D.R., Dewey D.H., Dedolph R.R., Automated system for determining respiratory gas exchange of plant materials, J. Amer. Soc. Hort. Sci. 94 (1969) 138-141.

[16] Nakano Y., Asada K. Hydrogen peroxide is scavenged by ascorbate-specific peroxidase in spinach chloroplasts, Plant Cell Physiol. 22 (1981) 867-880.

[17] Dalton D.A., Russel S.A., Hanus F.J., Pascoe G.A., Evans H.J., Enzymatic reactions of ascorbate and glutathione that prevent peroxidative damage in soybean root nodules, Proc. Nat. Acad. Sci. 83 (1986) 3811-3815.

[18] McCord M., Fridovich L., Superoxide dismutase. An enzymic function for erythrocuprein (hemocuprein), J. Biol. Chem. 244 (1969) 6049-6055.

[19] Patra M. L., Kar M., Mishra, D., Catalase activity in leaves and cotyledons during plant development and senescence, Biochem. Physiol. Pflanzenphys. 172 (1978) 385-390. 
[20] Huber D.J., The role of cell wall hydrolases in fruit softening, Hort Rev. 5 (1983) 169-219.

[21] Lingle S.E., Dunlap J.R., Sucrose metabolism in netted muskmelon fruit during development, Plant Physiol. 84 (1987) 386-389.

[22] McCollum T.G., Huber D.J., Cantliffe D.J., Soluble sugars accumulation and activity of related enzymes during muskmelon fruit development, J. Amer. Soc. Hort. Sci. 113 (1988) 399-403.

[23] Schaffer A.A., Aloni B., Fogelman E., Sucrose metabolism in developing fruit of Cucumis, Phytochem. 26 (1987) 1883-1887.

[24] Lee D.R., Water in plant storage tissues, in: Phloem Transport, Cronshaw J., Alan R. (Eds), Liss, New York, 1986, pp. 327-328.

[25] Awad M., Young R.E., Postharvest variation in cellulase, polygalacturonase and pectin methylesterase in avocado (Persea americana Hill cv. Fuerte) fruits in relation to respiration and ethylene production, Plant Physiol. 64 (1979) 306-309.

[26] Cadenas E., Biochemistry of oxygen toxicity, Annu. Rev. Biochem. 58 (1989) 79-110.
[27] McCord J.M., Day E.D., Superoxide-dependent production of hydroxyl radical catalyzed by iron-EDTA complex, FEBBS Lett. 86 (1978) 139-142.

[28] Rabinowitch H.D., Fridovich I., Superoxide radicals, superoxide dismutases and oxygen toxicity in plants, Photochem. Photobiol. 37 (1983) 679-690.

[29] Donovon D.H., Menzel B.D., Mechanisms of lipid peroxidation, iron catalyzed decomposition of fatty acid and hydroperoxides as the basis of hydrocarbon evolution in vivo, Experientia 34 (1978) 775-776.

[30] Elstner E.F., Pils I., Ethane formation and chlorophyll bleaching in DCMU-treated Euglena gracilis cells and isolated spinach chloroplast lamellae, Z. Naturforsch. 34 (1979) 1040-1043.

[31] Demmig-Adams B., Winter K., Krugar A., Czygan F.-C., Carotenoids and photoprotection in plants: a role for the xanthophyll zeaxanthin, Biochim. Biophys. Acta 1020 (1990) $1-24$.

\section{Caracterización fisicoquímica de la senescencia postcosecha del melón tardío 'Tendral'.}

Introducción. El melón 'Tendral' de tipo Cantalupo es una fruta de invierno con la piel verde oscura con un ligero reticulado; tiene una carne dulce y blanca y posee una larga vida de almacenamiento. Material y métodos. La senescencia del mesocarpo del melón de invierno Cucumis melo L (grupo inodorus) Tendral, almacenado a $12{ }^{\circ} \mathrm{C}$ y con cerca del $75 \%$ de humedad relativa, fue examinada durante 100 días después de la cosecha. Resultados. Durante el almacenamiento, el almidón y la sacarosa fueron cada vez más hidrolizados mientras que las tasas de azúcares reductores aumentaban. Durante este periodo, la consistencia y la acidez titulable disminuyeron, pero las concentraciones en proteínas y lipoperóxidos se incrementaron. Los parámetros de color $\mathrm{L}$, a y b también se vieron afectados, el parámetro b fue el que más aumentó después de la cosecha. La concentración de etileno permaneció mínima, pero la producción de anhídrido carbónico cambió de forma significativa. Las actividades de la catalasa y de la glutación reductasa aumentaron, mientras que las del ascorbato peroxidasa y superóxido dismutasa fueron inhibidas. Discusión. La senescencia del melón tardío Tendral está ligada al consumo de almidón y sacarosa y a la síntesis de los ácidos orgánicos necesarios para el metabolismo respiratorio. El peróxido de hidrógeno y el superóxido parecen también acumularse provocando una lenta lipoperoxidación de las membranas celulares.

Portugal / Cucumis melo / fisiología postcosecha / propiedades fisicoquímica / almacenamiento / calidad 